\title{
English as a Medium of Instruction: My Experience from a Nepali Hinterland
}

\author{
Ashok Raj Khati
}

\begin{abstract}
I have observed that many public schools are adopting English as a medium of instruction (EMI) in Nepal for a decade. During my last visits to lower parts of Mt. Everest region, some school principals stated, with a great enthusiasm, that they are gradually replacing Nepali with English as the medium of instruction up to secondary level even though there is lack of research and case studies to find whether such a shift is a boon or bane. It is already the most discussed issue at both global and local educational discourses and policies. Based on my own experience, observation and theoretical knowledge, I, in this paper, make attempts to analyze the EMI situation in Nepal with reference to some questions associated with it. I also suggest that a transitional model of language education is appropriate for multilingual country like Nepal.
\end{abstract}

Key words: English as a medium of instruction (EMI), experience, Nepal

\section{Introduction}

Being a teacher as well as teacher-educator, I have visited many public schools and interacted with guardians, students and teachers in Nepal. What I observed during my visits in past five years is that there is a growing attraction of EMI among most head teachers, parents and even some bureaucrats. Some of the head teachers and school management committee (SMC) members confidently pronounced that they have implemented EMI. Likewise, there has been a growing discussion among Nepali scholars over the EMI phenomenon in recent years. There is already the increasing shift to the use of EMI in South Asian context. With special focus on the university sector, Kirkpatrick (2014) mentioned that except for a few universities which are employing and implementing their own language education policies, majority of the East and South-East Asian universities have increased EMI programs as to embrace internalization. He further found that these universities in Asia have adopted EMI programs to attract international students as well as to stop national students going overseas in Anglophone countries. At global ELT discourse too, it is a growing phenomenon in both public and private education in all stages of education (primary, secondary and tertiary) across the world (Dearden, 2014).

A medium of instruction (MI) is a language used in teaching. It may or may not be the official language of the country. Nepal, as one of the developing countries that has not yet 
been able to sustain a single educational policy with full effects, is now implementing EMI education in public schools. It has also been receiving a huge attention from language policy researchers as well. (Shah, 2015). Therefore, it is an area worth to be discussed.

\section{Looking EMI into back}

When reflecting back to the history of medium of instruction policy in Nepal, Jung Bahadur Rana, a powerful Rana Prime Minister, had established Durbar (Palace) School after his return from Europe as he was greatly influenced by the use of English in the west. However, it was open only to members of the Rana family. Thus, the first government-run school in Nepal practiced EMI. Likewise, the first post-secondary educational institution in Nepal, Trichandra College, opened in 1918, also practiced EMI in its beginning days.

The government of Nepal showed interest in cultural unification only after 1950. The slogan of ekbhasha, ekbhesh, ek dharma, ekdesh (one language, one costume, one religion, one nation) summarized the goals of the Panchayat government, which attempted to spread Nepali, Hinduism, and other symbols of nation throughout the country to create a unified national identity (Rai et al., 2011). Throughout the Panchayat era, the goals of education were to promote development through unification of the nation under one language and culture. Education in Nepali medium of instruction became accessible to common people instead of a privilege for elites with the goal of bringing the whole population into a unified national identity (Weinberg, 2013). Thus, Nepali was the mandatory medium of instruction and all other languages including English were discouraged in the period 1952-1990. From the language policy perspective, Panchayat was the darkest age as languages other than Nepali were banned not only in the classroom but also in the playground following the doctrine ekdesh, ekbhasa, ek dharma (one nation, one language, one religion) adopted by the country at the time (Phyak, 2015:269). After the restoration of democracy in 1990, many private English medium schools started EMI from grade one and public schools followed the same pattern.

\section{Shifting into EMI}

During my visits to Solukhumbu in the last three years, I was able to produce data through open unstructured interviews and observation. I had talked to two head teachers, two parents, three teachers, two students and a teacher trainer in lower part of Solukhumbu. I took notes while I interviewed them and made observation of classrooms. I mostly maintained daily journal which was also a part of my job there.

My observation shows that many public school authorities are basically shifting their medium of instruction to English from Nepali in order to attract the large number of students who are now attracted to private English medium schools. Supporting this, one of the public school principals from Solukhumbu articulates his views in this way:

English is a global language, and it functions as an international lingua franca. EMI helps students connect countryside with the global world and offers them boundless opportunities. In addition, it is the language of global business and technology. If I had not implemented EMI in my school, many children would have joined the private school. Still, we are not able to increase the number of students at 
primary level. The government has already cut down the teachers' quotas for primary section due to less number of students. EMI is producing better results to increase enrollment in my school.

Public schools are adopting EMI to increase the number of students so that they can retain quotas of teachers in school. Otherwise, schools lose the quotas of teachers from the government, if they do not have required number of students. More strikingly, teachers take for granted that teaching in English helps students find job and participate in global community. They also believe that students' progress in the English language contributes to wider access to information and knowledge.

Likewise, parents also consider EMI as a gateway to join the global academic and economic community. They think that English creates better academic and economic opportunities. A guardian from Solukhumbu puts his views in this way:

English is obligatory in this competitive world. I want my children to learn English so that they will receive better academic offers at national and international arenas. Ultimately, it leads to a better life. Therefore, EMI in school is a right approach now.

From the case above, it has been obvious that parents have placed heavy pressure on school to adopt EMI. Both the teachers and guardians mean EMI leads to quality education. On the other hand, there have been a lot of critiques regarding whether English when adopted as medium of instruction in the school contributes to quality education. But a teacher trainer working in rural parts of Nepal has a bit different view in this regard:
When I observed the EMI situation in Taplejung, Ramechhap and Solukhumbu districts, I found that schools really do not know why they are adopting EMI. They only believe that it will improve their children's English and further it will stop children going to English medium schools. The implementation part of EMI is horrible in relation to teachers' proficiency levels, interaction inside the classroom and content delivery. The only positive aspect is that children build a large English vocabulary.

The following table shows a brief explanation for adopting EMI in this region:

Table 1: Reasons for adopting EMI

\begin{tabular}{|l|l|l|}
\hline SN & Participants & Reasons \\
\hline 1 & Head teachers & $\begin{array}{l}\text { EMI increases the } \\
\text { number } \\
\text { students. }\end{array}$ \\
\hline 2 & Teachers & $\begin{array}{l}\text { English offers the } \\
\text { opportunity of } \\
\text { lucrative jobs and } \\
\text { participation in } \\
\text { global community. }\end{array}$ \\
\hline 3 & Parents & $\begin{array}{l}\text { English provides } \\
\text { better academic } \\
\text { and professional } \\
\text { offers at national } \\
\text { and international } \\
\text { arenas. }\end{array}$ \\
\hline 4 & Teacher trainer & $\begin{array}{l}\text { EMI is a growing } \\
\text { attraction for all } \\
\text { stakeholders. }\end{array}$ \\
\hline
\end{tabular}

EMI and the classroom

In the schools with EMI, teachers have to depend on the textbooks prescribed by the government alone. Sadly, there is no any pedagogical support or teaching resources 
that can help the teachers to effectively conduct their classes in English medium. Very few teachers find EMI classroom pleasant and exciting in several content related subjects. Such teachers are either from English language teaching background or novice ones. They love speaking English in the classroom most of the time. They also invest more efforts to learn new words and phrases in English. On the other hand, most teachers who have been teaching in Nepali medium of instruction for decades in the past reported that they find EMI very challenging. They feel their schools adopting EMI has posed a burden in their profession. This tendency might hinder teaching learning activities. In this regard, a teacher from Southern part of Solukhumbu asserts:

I'm not confident enough to teach in English. I've been teaching in Nepali since last two decades. Now I am supposed to teach in English. Teaching in English is very challenging for me. I can't update myself at old age. Nor are we provided with any intensive training that can support and facilitate the EMI.

Another revealing part of my observation is that students are less involved in pair and group works. Nor are they found engaged in any type of project work as it is a must for learner centered approach. Generally, teachers introduce the lesson, talk to the students, explain the teaching items, translate them and provide little notes on the board. However, students' progress in building English vocabulary is a noticeable phenomenon through EMI. They generally seem to enjoy the lessons in all subjects with EMI in the beginning even if they can hardly read and write about social studies and science lessons.

Yet in another observation, use of translation method that was once abandoned by English teachers was found in application in the schools adopting EMI. School teachers are largely translating English texts into Nepali during classroom teaching. While in others, teachers only use English.

During the interaction with teachers, they have revealed that they did not make any assessment to find whether the students had comprehended their teaching in English. If the students failed to understand, the teachers were yet to come up with a proper strategy to help the students in their difficulties. All the teachers do not possess required proficiency level in English. And they do not bother about learning English either. They argue that they give emphasis on content, not language while teaching subjects - like in the teaching of mathematics, science and social studies.

With special reference to the experience of implementing EMI programs in schools of Mt. Everest region, Kathet, (2015) admits that many remote village community schools are taking the risk of implementing EMI. He observes that lack of communicative skills in English among teachers is one of the major challenges. In this light, lack of EMI qualified teachers has become a global challenge. Even if the requirement of EMI qualified teachers is not clear yet, a study carried out by British Council in 2015 [in which 55 countries participated] also shows that $83 \%$ of the countries responded that they did not have enough qualified teachers to handle EMI situation.

\section{The impact of EMI on learning}

The brief background of EMI setting might not capture all other contexts, but it certainly sets a scenario of EMI implementation and its impact on broader educational practices in Nepal. Parents and children have been influenced by the global

$26 \quad$ Journal of NELTA, Vol 21 No. 1-2, $\quad$ December 2016 
academic and career offers, advancement in technology and access to information. They firmly believe that English opens the door to build global networks, ties and relations. EMI has brought significant progress in increasing the learning achievements of students in some cases. Baral (2015) rightly mentioned that the SLC result of 2013/14 has shown that the schools that produced encouraging results were found to be adopting EMI, taking an example of Kanti and Kalika schools of Butwal, Shanti school of Manigram. Similarly, schools of Biratnagar, Pokhara, Surkhet, Kathmandu, Bhaktpur, Lalitpur, Damak, and Hetauda have proved the same level of results in Nepal. In the place where I visited in Solukhumbu, students' achievement in a few subjects like mathematics and English was found increased in lower grades, as no school had implemented EMI up to the $10^{\text {th }}$ grade. It has also brought changes inEnglish language being exposed to it and expressing the ideas in reading and writing in several academic subjects.

However, comprehension part of the students is not clear. The increased learning achievement might need further justification and statistics to see whether other factors or EMI alone contributes to this increase. Teachers report that many students from early grades fail in science and social studies because of the sudden shifting into EMI. Their views reflect that students understand the content better in their first language.

The other side of the impact is the growth of other national languages in which children are believed to learn and comprehend better than any other second or foreign language. In many cases of EMI in Nepal, students are punished if they use their mother tongue inside classroom or school. They are forced to generate knowledge and internalize the meaning of content taught in English. It raises the question of cognitive development of learners. Hence, is EMI a medium of instruction for other academic subjects, or is it the sole objective at all? In a nutshell, the question of whether EMI is producing satisfactory learning outcomes still remains unanswered and needs further explorations.

\section{EMI ahead}

There are questions regarding EMI implementation and the age of students. At which age is EMI to be incorporated? What is the justification for its appropriateness at grade one? What is the progress of students with EMI of different ages at different levels in relation to learning outcomes? These questions certainly need further inquiry. In addition, public schools do not have any definite guidelines to implement EMI. Policy only allows choosing English or Nepali.

The medium of instruction for school education shall be Nepali, English or both, whereas primary education can be provided in the mother tongue (first language). Language (as a subject) shall be taught in the same language (CDC, 2008).

The policy does not have comprehensive arrangement and facilitation plans to support the schools that implement EMI. In this connection, a few years ago, a famous applied linguist Alan Davies, who led the first ELT Survey in Nepal in 1983-1984, stated that the decisions regarding language education in Nepal are guided by sentimental role rather than instrumental. Sentimental role emphasizes the importance of a language to maintain group traditions and culture and to demonstrate differentiation from other groups while the instrumental role concerns 
the value of language learning for job and other economic prospects (Davies, 2009).

Next element of the analysis is teachers' English language proficiency level required for EMI. My observation shows that teachers are forced to teach through EMI in many cases. Many public schools have been implementing EMI policy without qualified teachers. It is entirely unclear what the requirements are with reference to English language competence. Many EMI teachers do not see themselves as English language teachers. They consider their job as a facilitator of students towards better learning content deliberations through better comprehension.

On the other hand, teaching through second or foreign language is entirely a different issue from teaching academic subjects through the first language. As EMI is concerned with language teaching pedagogy, there are questions that require further discussion. Are teachers, dealing with EMI, aware of foreign language pedagogy in a multilingual context? Are they familiar with the process of communication through second or foreign language in the classroom? Is effective communication in English happening in those classrooms? In most instances, formulaic use of English is being observed. Students memorize the phrases and words, even sentences, most of the time. If the subject to be taught does not have meaningful relationship with the outside world, learning cannot take place. How we can ensure effective communication in the classroom in English among teachers and students in various academic subjects is a crucial issue in EMI settings.

The use of students' home or community language is seen in all EMI schools I have observed. In many classrooms excessive use of Nepali has been observed. If the teachers are not proficient enough in English, they certainly use students' home language. In this regard, what is the effect of using and not using L1 in students'learning? A clear guideline is essential. With reference to teacher preparation, there has not been any uniform teacher training modality developed yet to assist EMI in Nepal. NCED (National Centre for Education Development), the apex body for human resource development in school education, has not institutionally materialized the teacher training model for EMI purpose. Nor there is any space for EMI in current 'teacher professional development' model of teacher training. It shows that EMI has not been a priority in policy under the Ministry of Education. Furthermore, on theoretical ground, there are doubts in the training manuals designed and implemented for EMI purpose by several organizations in Nepal. For example, some training sessions are merely translation while others are full of pair and group works. Ministry of Education and its associate agencies need to think over a uniform teacher training model for EMI purpose which can be a basis for training at different levels.

Similarly, many head teachers are found confused with which subjects to be taught through EMI. For instance, many private English medium schools teach social studies in Nepali medium, while this subject is taught in English in public schools. The basis for decision is not clear yet. The decisions are not based on the effectiveness of learning process and outcome from the medium of instruction implemented in schools.

Therefore, a few linguists and ELT professionals has always emphasized the effective teaching of compulsory English.Kansakar (2011) questions: how can we expect effective teaching and learning of

$28 \quad$ Journal of NELTA, Vol 21 No. 1-2, $\quad$ December 2016 
other subjects in English in the context that we are struggling hard to teach English as a compulsory subject from Grade 1 to university level?

With this backdrop, I conclude this section with Phyak (2015) who has aptly mentioned: "English language certainly has an important space in global multilingualism particularly to access globally available socio-economic and educational resources. However, this taken-for-granted assumption does not work quite well in education (teachinglearning process) particularly in the context where children speak languages other than English outside classroom (For many children in Nepal, English is the third language and they do not need to use English in their everyday social interactions)." The success in understanding of the contents of curricula largely depends upon whether or not the language used as the medium of instruction in school is comprehensible to students.

\section{Conclusion}

EMI is unquestionably a growing phenomenon in public education in Nepal. It has been beneficial to improve the students' English as it provides maximum exposure to them through speech, reading and writing in several subjects. EMI is thought to open the door of possibilities for lofty academic and economic offers at local and international level; nonetheless there are suspicions over how many students from public schools have this opportunity. Furthermore, EMI in Nepal is being promoted very powerfully, and the phenomenon is more idealistic in nature. However, it has been a contested issue in Nepali academia for both political and pedagogical reasons. Most importantly, researchers have critiques on the weak pedagogical aspect of EMI in multilingual situation, particularly on the process of communication inside the classroom. EMI has been implemented without any logical guidelines in public schools. It is being implemented with little or no preparation and planning at all. The phenomenon is not effective in terms of its impact on students' learning of several academic subjects.

With the increasing demand of English language for global integration, the choice of schooling children in English has been given a major priority in developing countries including Nepal. And, in fact, we cannot ignore the need for English as a global lingua franca. However, there are very limited success stories of EMI, and the successful countries evidently based the policy on appropriate educational principles. The ad hoc implementations are very likely to be counterproductive. (Shah, 2015) In Nepal's case, the policy regarding EMI is not comprehensive, nor is it academically and practically desirable. It is more covert in nature leaving the things up to the market. The English language related policies and practices have been implemented without considering the educational cost and benefit in Nepal. The sole logic behind the current shift is globalization and market forces.

Thus, EMI has also been a key selling point in the market in the guise of the ideology of quality education, which at present remains a myth. It has been projected as a commodity in the market. But very few students have access to the global and local market resources available in English. Incorporating a foreign language at the early foundation of education is not academically sound policy. Nepal needs to formulate multilingual model of language policy and planning. EMI planning, on the other hand, needs to be guided by the transitional model - from local language to 
official language to international language from early grades to university level.

\section{References}

Baral, K.R. (2015). Parents have rights to choose medium of instruction: Executive Director of NCED [Blog article]. ELT Choutari. Retrieved from http:// eltchoutari.com/2015/08.

CDC (2008). Curriculum Development Centre. Author: Sanothimi Bhaktapur.

Davies, A. (2009). Professional advice vs political imperatives. In J.C. Alderson (Ed.), The politics of language education: Individuals and institutions ( $p p .45-63$ ). Bristol: Multilingual Matters.

Dearden, J. (2014). English as a medium of instruction-a growing global phenomenon. London; British Council.

Kansakar, T. R. (2011). The theory, practice and pedagogy of English as a foreign language in Nepal. In L. Farrell, U.N. Singh, \& R.A. Giri (Eds.), English language education in South Asia New Delhi: Cambridge University Press. (pp. 123-135).

Kathet, M. (2015). EMI in community schools: A case from Mt. Everest region. [Blog article]. ELT Choutari. Retrieved from http://eltchoutari.com/2015/08.

Kirkpatrick, A. (2014). English as a medium of instruction in East and Southeast Asian universities. In N.M. \& A. Scarino (Ed.), Dynamic ecologies: A relational perspective on languages education in the Asia-Pacific region (pp. 15-30). Germany: Springer.

Phyak, P. (2015). Reimagining EMI from multilingual perspective policies/ practices, realities and looking forward.
[Blog article]. ELT Choutari. Retrieved from http://eltchoutari.com/2015/08.

Rai, V.S., Rai, M., Phyak, P., \& Rai, N. (2011). Multilingual education in Nepal: Hearsay and reality. Kathmandu, Nepal: UNESCO.

Shah, P.K. (2015, August). English medium instruction (EMI) in Nepalese education: potential or problem? [Blog article]. ELT Choutari. Retrieved from <http:// eltchoutari.com/2015/08/englishmedium-instruction-emi-in-nepalese educationpotential-or-problem/>.

Weinberg, M. (2013). Revisiting history in language policy: The case of medium of instruction in Nepal. Working Papers in Educational Linguistics, 28(1), 61-80.

The Author: Ashok Raj Khati is a faculty at the Department of English Language Education, Gramin Adarsha Multiple Campus, Kathmandu affiliated with Tribhuvan University Nepal. He is a former central executive member of NELTA. He currently works for Rural Education and Environment Development Centre (REED Nepal), Pulchock Lalitpur in the capacity of a teacher training specialist. Mr. Khati is a promising academic writer. 